\title{
Study of Substituent Effect on Properties of Platinum(II) Porphyrin Semiconductor Using Density Functional Theory
}

\author{
Harno Dwi Pranowo*, Fadjar Mulya, Hafiz Aji Aziz, and Grisani Ambar Santoso \\ Austrian-Indonesian Centre for Computational Chemistry, Department of Chemistry, \\ Faculty of Mathematics and Natural Sciences, Universitas Gadjah Mada, \\ Sekip Utara, Yogyakarta, 55281, Indonesia
}

Received June 20, 2017; Accepted January 25, 2018

\begin{abstract}
Study of substituent effect on properties of platinum(II) porphyrin had been performed using the DFT method. The aim of the study is to investigate the effect of a substituent group on the electronic and optical properties of the platinum(II) porphyrin. Geometry optimization was conducted using DFT/B3LYP/LANL2DZ to obtain the molecular structure, electronic structure and energy profile. Band gap energy $\left(E_{g}\right)$, the density of states (DOS), and UV-visible spectra are the semiconductor parameters to study. Computational results show that platinum(II) porphyrin and substituted platinum(II) porphyrin have properties of semiconductor based on $E_{g}$ value, DOS, and UV-visible spectra. The results show that Mulliken partial charges of electron withdrawing substituents are higher than the electron donating substituents $\left(\mathrm{CH}_{3}, \mathrm{OH}\right.$, and $\left.\mathrm{NH}_{2}\right)$. $E_{g}$ values of the complexes with respect to the substituents follow this order: $\mathrm{NH}_{2}<\mathrm{OH}<\mathrm{NO}_{2}<\mathrm{COOH}<\mathrm{I}<\mathrm{CH}_{3}<\mathrm{Br}<\mathrm{F}<\mathrm{H}$, for DOS HOMO values, the order is $\mathrm{CH}_{3}<\mathrm{NO}_{2}<\mathrm{I}<\mathrm{OH}<\mathrm{F}<$ $\mathrm{NH}_{2}<\mathrm{COOH}<\mathrm{Br}<\mathrm{H}$ and the maximum wavelength $\left(\lambda_{\text {max }}\right.$ ) for UV-visible adsorption spectra follows this order: $\mathrm{NH}_{2}>$

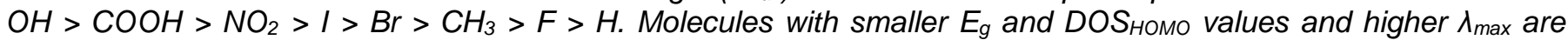
considered as the most appropriate semiconductor materials. Our results show that Pt(II)P-NH has the smallest $E_{g}$ and the highest $\lambda_{\max }$ among other substituted platinum(II) porphyrin molecules. Therefore, Pt(II)P-NH $\mathrm{N}_{2}$ are the most suitable semiconductor material based on the aforementioned criteria.
\end{abstract}

Keywords: platinum(II) porphyrin; semiconductor; substituent effect

\section{ABSTRAK}

Kajian pengaruh substituen terhadap sifat semikonduktor platina(II) porfirin dilakukan dengan metode DFT. Tujuan dari penelitian ini adalah untuk mempelajari pengaruh substituen terhadap sifat elektronik dan optik kompleks platina(II) porfirin. Optimasi geometri dilakukan dengan menggunakan metode DFT/B3LYP/LANL2DZ terhadap kompleks platina(II) porfirin sehingga diperoleh stuktur dan sifat elektronik kompleks. Celah pita $\left(E_{g}\right)$, rapat keadaan (DOS) dan spektra serapan UV-Vis menjadi paramater sifat semikonduktor kompleks platina(II) porfirin. Hasil perhitungan menunjukkan bahwa muatan parsial Mulliken dari substituent penarik elektron lebih tinggi dibandingkan dengan substituen pendorong elektron. Harga $E_{g}$ dari kompleks dengan substituent adalah: $\mathrm{NH}_{2}<\mathrm{OH}<\mathrm{NO}_{2}<\mathrm{COOH}$ $<\mathrm{I}<\mathrm{CH}_{3}<\mathrm{Br}<\mathrm{F}<\mathrm{H}, \mathrm{DOS} \mathrm{HOMO}_{\mathrm{O}} \mathrm{CH}_{3}<\mathrm{NO}_{2}<\mathrm{I}<\mathrm{OH}<\mathrm{F}<\mathrm{NH}_{2}<\mathrm{COOH}<\mathrm{Br}<\mathrm{H}$ dan spektra UV-Visible: $\mathrm{NH}_{2}>$ $\mathrm{OH}>\mathrm{COOH}>\mathrm{NO}_{2}>\mathrm{I}>\mathrm{Br}>\mathrm{CH}_{3}>\mathrm{F}>\mathrm{H}$. Kita membutuhkan kompleks platina(II)porfirin yang memiliki nilai $\mathrm{E}_{g}$ dan $D O S_{\text {номо }}$ yang paling kecil dan spectra UV-Visible yang paling panjang. Kita dapat menyimpulkan bahwa Pt(II)P-NH memberikan performa terbaik dari paramater $E_{g}$, DOS dan spectra UV-Visible, oleh karena itu Pt(II)P-NH ${ }_{2}$ dapat direkomendasikan sebagai material semikonduktor yang sangat potensial.

Kata Kunci: platina(II) porfirin; semikonduktor; pengaruh substituen

\section{INTRODUCTION}

Porphyrins are an organic-macrocycle compound that is ubiquitous in the world, and they have been called the pigment of life [1]. It has identical conjugatedframework consisting of single bonds (C-C, C-N, C-H, N$\mathrm{H})$ and double bonds $(\mathrm{C}=\mathrm{C}$ and $\mathrm{C}=\mathrm{N})$. The electroluminescence of porphyrin evidence that porphyrin is the composer of semiconductor materials. Porphyrin

* Corresponding author

Email address : harnodp@ugm.ac.id can be modified by adding substituent, adding metal ion in the center, or enlarging macrocyclic system.

Structures, properties and applications of metalloporphyrin complexes have been extensively studied both experimentally [2-6] and theoretically [713]. Metalloporphyrin has various structures starting from planar to concave depending on the central ions and substituent group due to the distortion effects [3]. The semiconducting properties of metalloporphyrin DOI: 10.22146/ijc.26121

Harno Dwi Pranowo et al. 
show that the small energy gap and the high electron density above the Fermi level can be used as the sensitizer on the dye-sensitized solar cell [4-10]. Metalloporphyrin complexes' electronic properties can be modified by changing the central ion and adding substituent group that can affect their electronic band gap and electronic absorption spectra [5-6,10].

Among all of the metalloporphyrins, the platinum(II) porphyrin seems to be a good candidate for a new semiconductor such as an organic light emitting diode (OLED) and photosensitizer [14-16]. Pt(II)-porphyrin is a low-spin diamagnetic complex as shown experimentally [16-18], however, the studies on the substituent effects on both structural and electronic properties of $\mathrm{Pt}$ (II)-porphyrin are the best insufficient. Because of that, we decided to conduct a theoretical study focusing on the substituent effects on the structural and electronic properties of $\mathrm{Pt}(\mathrm{II})$ porphyrin. The properties of the substituted $\mathrm{Pt}(\mathrm{II})$ porphyrin with $\mathrm{CH}_{3}, \mathrm{~F}, \mathrm{I}, \mathrm{Br}, \mathrm{COOH}, \mathrm{NH}_{2}, \mathrm{OH}$ and $\mathrm{NO}_{2}$ will be compared with the properties of pristine $\mathrm{Pt}$ (II) porphyrin. The effects of the different types of the substituents, i.e. electron donating or electron withdrawing will be further discussed. Several studies show that substituent can affect not only the UV-Visible spectra but also the geometry of metalloporphyrin [11-12].

\section{COMPUTATIONAL METHODS}

\section{Materials}

Platinum(II) porphyrin complex with electron donating $\left(\mathrm{CH}_{3}, \mathrm{OH}\right.$, and $\left.\mathrm{NH}_{2}\right)$ and withdrawing substituents $\left(\mathrm{NO}_{2}, \mathrm{COOH}, \mathrm{I}, \mathrm{Br}, \mathrm{F}\right)$ on meso position $(\mathrm{R})$, as shown in Fig. 1(a).

\section{Instrumentation}

This research used a quad-core High Performance Computer (HPC) remotely accessed from Directorate of Systems and Information Resources, Universitas Gadjah Mada (UGM). All of the quantum mechanical calculations were performed using Gaussian 09 package [19]. Gauss Sum 2.2.5 [20] was used to calculate the density of states (DOS) of the complexes.

\section{Procedure}

\section{Geometry optimization}

Platinum(II) octa ethyl porphyrin (PtOEP) had been chosen as a parameter with XRD data result from Sheppard et al. [18]. The optimization was performed using DFT method with B3LYP hybrid functional and LANL2DZ basis set for all atoms. Charge and total spin multiplicity were set on either 0 or 1 depending on the electronic configuration of the molecules.
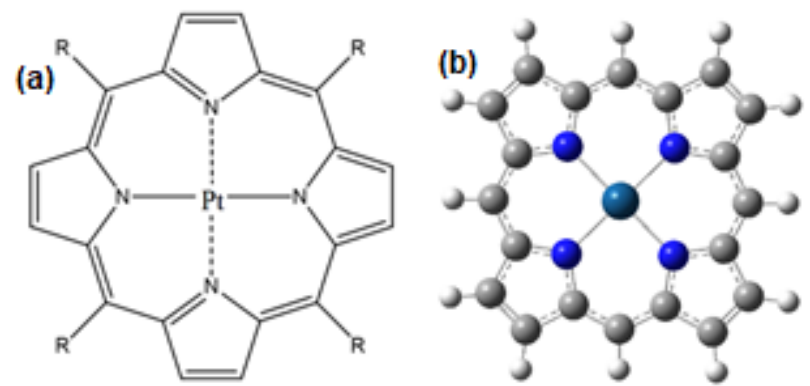

Fig 1. Structure of (a) $\mathrm{Pt}(\mathrm{II})$-porphyrin substituted $\mathrm{R}$ and (b) the optimized geometry of $\mathrm{Pt}(\mathrm{II})$-porphyrin
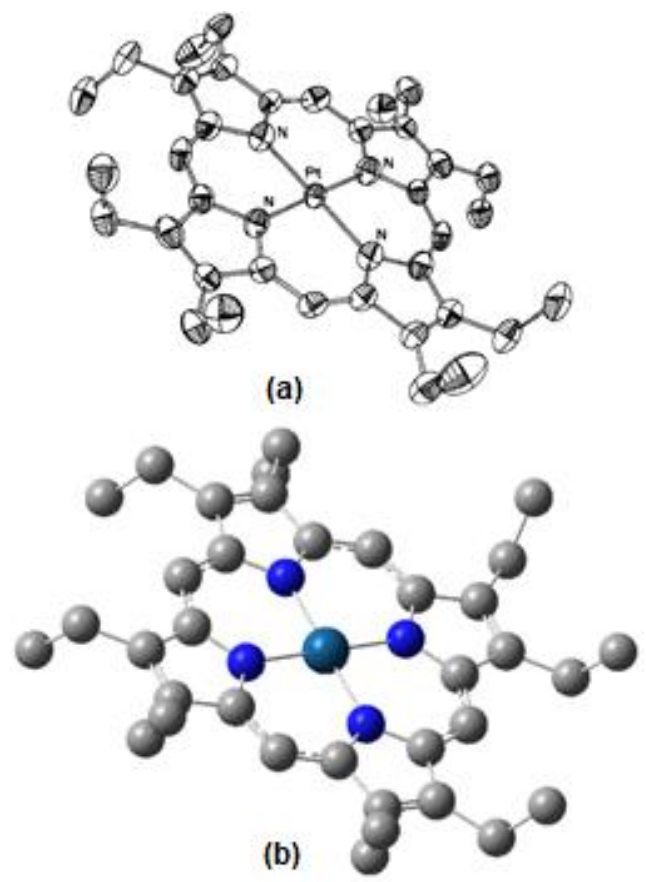

Fig 2. Platinum(II) octaethylporphyirin (PtOEP) from XRD (Sheppard,1988) (a) and the result geometry optimization with DFT/LANL2DZ/B3LYP (b)

\section{Calculation of the electronic properties}

The UV/Vis absorption spectra calculation was conducted using time-dependent DFT method on the optimized ground state complex with 10 states $(\mathrm{N}=10)$. The functional and the basis set were similar with the ground state energy optimization calculation. Calculation of DOS was performed on the optimized ground state complex with the energy range from -10.0 to $0.00 \mathrm{eV}$ with the peak width of 0.30 , based on the HOMO-LUMO energy range of the molecules.

\section{RESULT AND DISCUSSION}

\section{Ground State Geometry}

The computationally optimized structure for the unsubstituted $\mathrm{Pt}(\mathrm{II})$-porphyrin complex was compared 
with the XRD data (Fig. 2(a)). The mean standard deviation (MSD) of the bond length is approximately $1.22 \%$ and the MSD of the bond angle is approximately about $0.16 \%$ (Table 1 and 2 ). The optimized theoretical structure of $\mathrm{Pt}(\mathrm{II})$-porphyrin (Fig. 1(b)) and experimental PtOEP (Fig. 2(b)) are both square planar. This shows that our employed method is sufficient to reproduce the experimental observation. However, in contrast with our hypothesis, the substituents do not give any significant effect on the structure of the complexes. The substituted complexes retain the square planar structure compared to the unsubstituted complexes, as displayed in Table 3. The table shows that both of bond angle and bond length of complexes have a similar structure. Theoretically, the structure is square planar, we can conclude that electron donating substituent $\left(\mathrm{CH}_{3}, \mathrm{OH}\right.$, and $\left.\mathrm{NH}_{2}\right)$ and electron withdrawing substituent $\left(\mathrm{NO}_{2}, \mathrm{COOH}, \mathrm{I}, \mathrm{Br}, \mathrm{F}\right)$ did not affect the structure of $\mathrm{Pt}(\mathrm{II})$-porphyrin.

\section{Mulliken Partial Charges}

Population analysis is a mathematical way of partitioning a wave function or electron density into charges on the nuclei, bond orders and other related information. Atomic charges cannot be observed experimentally because they do not correspond to any unique physical property. In reality, atoms have a positive nucleus surrounded by negative electrons, not partial charge on each atom.

Condensing electron density and nuclear charges down to partial charges on the nucleus results in an understanding of the electron density distribution. The nucleophilic/electrophilic partial charges correspond well to the chemist's view of the ionic or covalent bond, polarity and others. Organometallics typically have charges on the order of \pm 0.5 .

The fundamental assumption of Mulliken Population Analysis used by the Mulliken scheme for partitioning the wave function is that the overlap between two orbitals is shared equally. This method is often used for understanding chemistry rather than quantitatively predicting experimental results [21].
Substituent group will affect the charge density of organometallic compound. In this research, we modified platinum(II) porphyrin with electron donating and electron withdrawing group. Theoretically the electrondonating group is an activating group so that it gives atomic charge being negative. On the other hand, an electron-withdrawing group is a deactivating group. Hence, the atomic charge will be positive.

Based on theory, Table 4 shows that the electron donating substituent $\left(\mathrm{CH}_{3}, \mathrm{OH}\right.$, and $\left.\mathrm{NH}_{2}\right)$ gave the Mulliken partial charges lower than electron withdrawing substituent $\left(\mathrm{NO}_{2}, \mathrm{COOH}, \mathrm{I}, \mathrm{Br}, \mathrm{F}\right)$. It is caused by the

Table 1. Comparison of bond length XRD PtOEP and calculation DFT/LANL2DZ/B3LYP

\begin{tabular}{lccc}
\hline \multicolumn{1}{c}{ Bond } & XRD $(\AA)$ & Calculation $(\AA)$ & Deviation $(\%)$ \\
\hline Pt-N1 & 2.012 & 2.044 & 1.592 \\
Pt-N1a & 2.012 & 2.044 & 1.586 \\
N1-CA1 & 1.376 & 1.391 & 1.144 \\
CA1-CB1 & 1.453 & 1.462 & 0.669 \\
C7-C8 & 1.521 & 1.554 & 2.169 \\
Pt-N2 & 2.013 & 2.044 & 1.540 \\
Pt-N2A & 2.014 & 2.044 & 1.487 \\
N1-CA2 & 1.382 & 1.391 & 0.692 \\
CA1-CM2A & 1.377 & 1.394 & 1.265 \\
CB1-C1 & 1.505 & 1.509 & 0.299 \\
CB2-C3 & 1.509 & 1.509 & 0.033 \\
CM1-CA3 & 1.365 & 1.394 & 2.152 \\
\hline
\end{tabular}

Table 2. Comparison of bond angles XRD PtOEP and calculation DFT/LANL2DZ/B3LYP

\begin{tabular}{lrcc}
\multicolumn{1}{c}{ Bond angles } & XRD $\left({ }^{\circ}\right)$ & Calculation $\left({ }^{\circ}\right)$ & Deviation $(\%)$ \\
\hline N1-PT-N2 & 90.001 & 89.997 & 0.004 \\
N2-PT-N1A & 90.010 & 89.997 & 0.014 \\
N2-PT-N2A & 180.000 & 179.890 & 0.061 \\
PT-N1-CA1 & 126.920 & 126.649 & 0.214 \\
CA1-N1-CA2 & 106.130 & 106.712 & 0.548 \\
N1-CA1-CM2A & 124.730 & 125.230 & 0.401 \\
N1-PT-N1A & 180.000 & 179.822 & 0.099 \\
N1-PT-N2A & 90.010 & 90.001 & 0.010 \\
N1A-PT-N2A & 90.010 & 90.004 & 0.007 \\
PT-N1-CA2 & 127.030 & 126.638 & 0.309 \\
N1-CA1-CB1 & 109.630 & 109.731 & 0.092 \\
\hline
\end{tabular}

Table 3. The structure parameters of $\mathrm{Pt}(\mathrm{II})-\mathrm{P}-\mathrm{R}$ complexes

\begin{tabular}{|c|c|c|c|c|c|c|c|c|c|c|}
\hline \multirow{2}{*}{$\begin{array}{l}\text { Substituent } \\
\text { Group }\end{array}$} & \multicolumn{4}{|c|}{ Bond Length $(\AA)$} & \multicolumn{6}{|c|}{ Bond Angle $\left({ }^{\circ}\right)$} \\
\hline & Pt-N1 & Pt-N2 & Pt-N3 & Pt-N4 & N1-Pt-N3 & N1-Pt-N2 & N1-Pt-N4 & N2-Pt-N4 & N2-Pt-N3 & N3-Pt-N4 \\
\hline $\mathrm{H}$ & 2.043 & 2.043 & 2.043 & 2.043 & 180.000 & 90.000 & 90.000 & 180.000 & 90.000 & 90.000 \\
\hline $\mathrm{CH}_{3}$ & 2.043 & 2.043 & 2.043 & 2.043 & 179.980 & 90.009 & 89.989 & 179.938 & 90.002 & 90.000 \\
\hline $\mathrm{F}$ & 2.042 & 2.042 & 2.042 & 2.042 & 179.999 & 89.999 & 89.999 & 179.997 & 90.002 & 89.999 \\
\hline I & 2.048 & 2.048 & 2.048 & 2.048 & 179.997 & 90.005 & 89.993 & 179.990 & 89.996 & 90.006 \\
\hline $\mathrm{Br}$ & 2.046 & 2.046 & 2.046 & 2.046 & 179.993 & 89.993 & 89.983 & 179.964 & 90.004 & 90.020 \\
\hline $\mathrm{NH}_{2}$ & 2.045 & 2.044 & 2.044 & 2.045 & 179.935 & 90.022 & 89.989 & 179.886 & 89.978 & 90.010 \\
\hline $\mathrm{NO}_{2}$ & 2.042 & 2.042 & 2.042 & 2.042 & 179.945 & 90.016 & 89.998 & 179.977 & 89.985 & 90.001 \\
\hline $\mathrm{OH}$ & 2.042 & 2.042 & 2.042 & 2.042 & 179.975 & 90.000 & 90.000 & 179.977 & 89.999 & 90.000 \\
\hline $\mathrm{COOH}$ & 2.041 & 2.041 & 2.039 & 2.041 & 179.932 & 90.108 & 90.097 & 179.766 & 89.899 & 90.097 \\
\hline
\end{tabular}


ability of the substituent to donate electron through the resonance of the porphyrin ring. Electron donating substituent has a high ability so that its increased electron density in porphyrin ring and decreased Mulliken partial charge $\mathrm{Pt}(\mathrm{II})$. On the other hand, electron-withdrawing substituent can withdraw electron from porphyrin ring through the resonance. Therefore, the Mulliken partial charges increase.

\section{Band Gap}

The electronic structure of metals, semiconductors and many other solids may be described in terms of band or zone theory. The chemical approach to band theory is to take molecular orbital theory. One of the molecular orbitals is bonding and has lower energy than that of the atomic orbitals. The other is antibonding and is of higher energy [22].

For a semiconductor, the band gap is the difference in energy between removing and adding an electron to the neutral solid; for a finite system this corresponds to the difference between the energies of the highest occupied Kohn-Sham orbitals of the neutral and anionic system [23]. The valence electron-electron interactions were modeled using a density functional theory (DFT) that the
Table 4. Mullikan charges and value of orbital level energy on complexes Pt(II)P-R

\begin{tabular}{|c|c|c|c|c|}
\hline $\begin{array}{l}\text { Substituent } \\
\text { Group }\end{array}$ & $\begin{array}{l}\mathrm{Pt}(\mathrm{II}) \text { charge } \\
\text { (Mulliken) }\end{array}$ & $\begin{array}{c}\text { EHOMO }_{\text {HO }} \\
(\mathrm{eV})\end{array}$ & $\begin{array}{c}\text { ELUMO } \\
(\mathrm{eV})\end{array}$ & $\begin{array}{c}E_{g} \\
(e V)\end{array}$ \\
\hline$\overline{\mathrm{H}}$ & 0.848 & -5.65 & -2.47 & 3.18 \\
\hline$F$ & 0.857 & -6.01 & -3.09 & 3.01 \\
\hline $\mathrm{Br}$ & 0.857 & -6.05 & -3.10 & 2.94 \\
\hline $\mathrm{CH}_{3}$ & 0.820 & -5.16 & -2.23 & 2.93 \\
\hline 1 & 0.860 & -5.93 & -3.03 & 2.90 \\
\hline $\mathrm{COOH}$ & 0.862 & -6.20 & -3.37 & 2.83 \\
\hline $\mathrm{NO}_{2}$ & 0.880 & -7.22 & -4.48 & 2.75 \\
\hline $\mathrm{OH}$ & 0.817 & -4.97 & -2.39 & 2.57 \\
\hline $\mathrm{NH}_{2}$ & 0.784 & -3.76 & -1.65 & 2.11 \\
\hline
\end{tabular}

Table 5. The DOS abundance on HOMO and LUMO orbital complexes Pt(II)P-R

\begin{tabular}{|c|c|c|}
\hline Complexes & $\mathrm{E}_{\mathrm{HOMO}}(\mathrm{eV})$ & $\mathrm{E}_{\text {LUMO }(\mathrm{eV})}$ \\
\hline $\mathrm{Pt}(\mathrm{II}) \mathrm{P}-\mathrm{CH}_{3}$ & 0.984 & 1.992 \\
\hline $\mathrm{Pt}(\mathrm{II}) \mathrm{P}-\mathrm{NO}_{2}$ & 0.988 & 1.994 \\
\hline Pt(II)P-I & 0.995 & 1.975 \\
\hline $\mathrm{Pt}(\mathrm{II}) \mathrm{P}-\mathrm{OH}$ & 0.996 & 1.919 \\
\hline $\mathrm{Pt}(\mathrm{II}) \mathrm{P}-\mathrm{F}$ & 0.997 & 1.956 \\
\hline $\mathrm{Pt}(\mathrm{II}) \mathrm{P}-\mathrm{NH}_{2}$ & 0.999 & 1.986 \\
\hline $\mathrm{Pt}(\mathrm{II}) \mathrm{P}-\mathrm{COOH}$ & 1.000 & 1.992 \\
\hline $\mathrm{Pt}(\mathrm{II}) \mathrm{P}-\mathrm{Br}$ & 1.000 & 1.947 \\
\hline $\mathrm{Pt}(\mathrm{II}) \mathrm{P}-\mathrm{H}$ & 1.982 & 1.992 \\
\hline
\end{tabular}
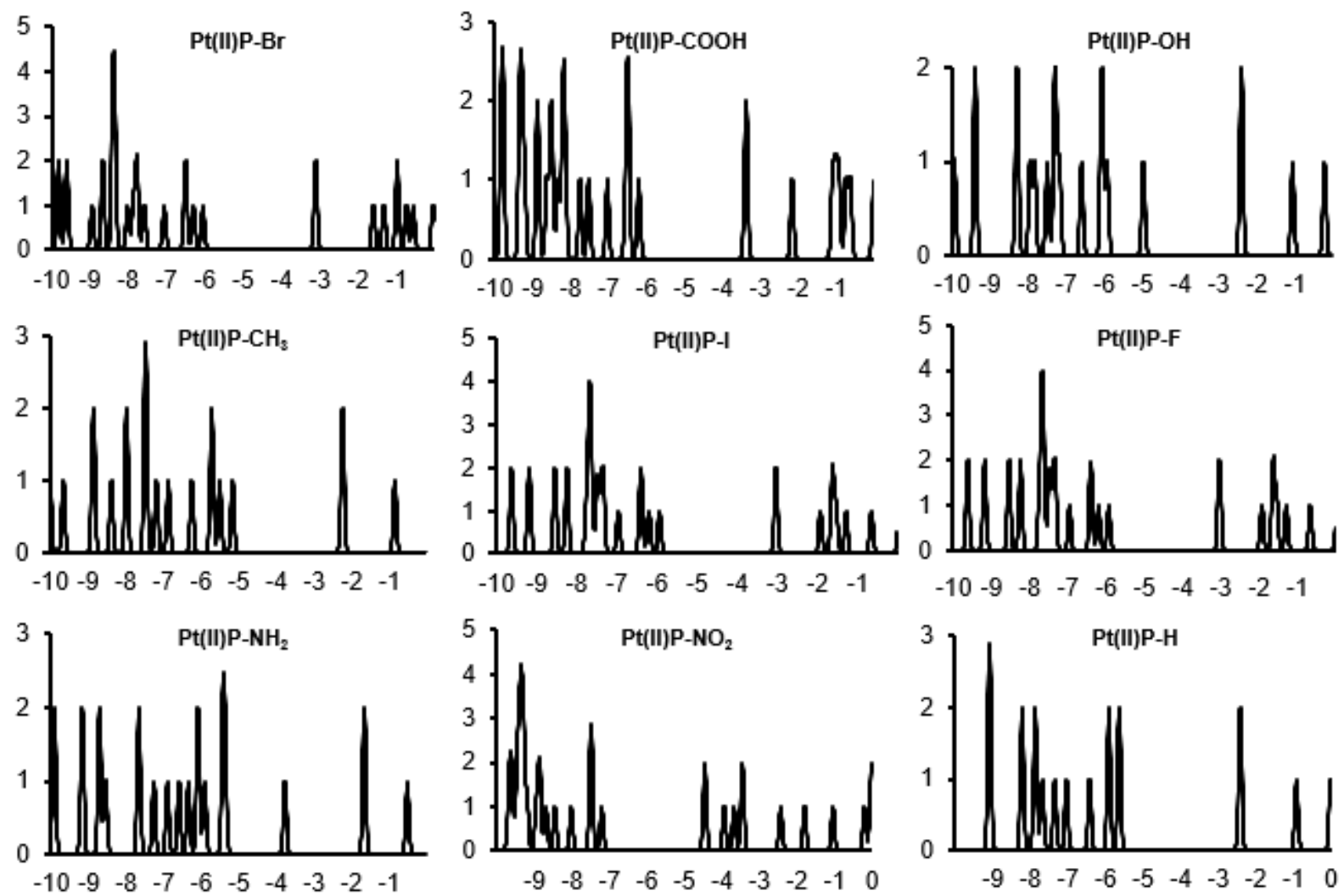

Fig 3. DOS spectra Pt(II)P-R with Gaussum 2.2.5 calculation 
approximations allow the development of an electronelectron potential using the electronic charge density [24].

The calculation of the structural properties of semiconductor is a good test of the accuracy of the Local Density Approximation (LDA) of the density functional theory [23]. In this research, we used B3LYP hybrid functional, which include LDA and GGA functionals. Based on previous study, B3LYP hybrid functional is the most accurate method compare with the other DFT functionals [25-26].

Mitchell defined that an $E_{g}$ value of material semiconductor is between 1.5-4.0 eV [27]. We can conclude that it will be easier for electron to be excited from orbital HOMO to orbital LUMO if the band gap energy is small. On the other hand, we have to keep track of the probability of recombination (further discussion in DOS section).

Table 4 shows the profile of band gap energy $\left(E_{g}\right)$ substituent group decreased the $E_{g}$ value. Electron donating substituents $\left(\mathrm{CH}_{3}, \mathrm{OH}\right.$, and $\left.\mathrm{NH}_{2}\right)$ tend to decrease the stability of orbital (HOMO and LUMO), which cause the increase of the level of orbital energy, in contrast, with the electron withdrawing substituents $\left(\mathrm{NO}_{2}\right.$, $\mathrm{COOH}, \mathrm{I}, \mathrm{Br}, \mathrm{F}$ ). This result related to Barbee's results [11] that $\mathrm{Pt}(\mathrm{II})-\mathrm{P}-\mathrm{NH}_{2}$ has the smallest $\mathrm{E}_{\mathrm{g}}$ value $(2.11 \mathrm{eV})$.

\section{Density of State (DOS)}

The density of states (DOS) is defined as the number of the states that can be occupied by electron on a given energy level. DOS can be used as a parameter to measure the probability of recombination to occur for any given initial and final energy states.

Table 5 and Fig. 3 show that the DOS abundance is affected differently by the substituents. DOS abundance in the LUMO has a similar value, disregard with the type of the substituents. It means that the type of the substituent group has no significant effects, LUMO is the empty orbital that can be occupied by excited electron. On the other hand, the type of the substituent affects DOS abundance in orbital HOMO. Electron donating substituents $\left(\mathrm{CH}_{3}, \mathrm{OH}\right.$, and $\left.\mathrm{NH}_{2}\right)$ tend to have smaller the complexes. We can conclude from the table that

DOS abundance than electron withdrawing $\left(\mathrm{NO}_{2}\right.$, $\mathrm{COOH}, \mathrm{I}, \mathrm{Br}$, and F). Orbital HOMO is occupied orbital so that substituent group affects the electron density in orbital.

Electron donating substituents increase the electron density on the molecule so that DOS Hомо abundance decreased. Table 5 showed the DOS Lumo abundance is higher than DOS номо. We can define that LUMO orbital has the number of states which can be occupied much more than $\mathrm{HOMO}$ orbital so that electron will easily excite to orbital LUMO. Otherwise, orbital $\mathrm{HOMO}$ has a variation of DOS abundance so that orbital HOMO has a variation of probability to be recombination. The higher DOSномо implies higher probability of recombination, which is an undesired property for a semiconductor material. We can conclude from Fig. 3 that electron-donating groups shift the HOMO orbital, while electron withdrawing groups shift the LUMO orbital to Fermi level.

\section{UV-Visible Spectra}

Sensitizer on the material semiconductor, which is applied in photocatalyst, should be designed to absorb light in visible range. Based on that fact, we calculated the UV-visible spectra of the complexes. Table 6 and Fig. 4 show that the substituent groups increase the maximum wavelength of the complexes (Bathochromic shift) following the Woodward-Fieser rules.

Electron donating substituents $\left(\mathrm{CH}_{3}, \mathrm{OH}\right.$, and $\left.\mathrm{NH}_{2}\right)$

Table 6. Absorption length of UV-Vis spectra $\mathrm{Pt}(\mathrm{II}) \mathrm{P}-\mathrm{R}$

\begin{tabular}{lc}
\hline \multicolumn{1}{c}{ Complexes } & $\lambda_{\max }(\mathrm{nm})$ \\
\hline $\mathrm{Pt}(\mathrm{II}) \mathrm{P}-\mathrm{NH}_{2}$ & 622.35 \\
$\mathrm{Pt}(\mathrm{II}) \mathrm{P}-\mathrm{OH}$ & 534.68 \\
$\mathrm{Pt}(\mathrm{II}) \mathrm{P}-\mathrm{COOH}$ & 457.38 \\
$\mathrm{Pt}(\mathrm{II}) \mathrm{P}-\mathrm{NO}_{2}$ & 440.44 \\
$\mathrm{Pt}(\mathrm{II}) \mathrm{P}-\mathrm{I}$ & 384.39 \\
$\mathrm{Pt}(\mathrm{II}) \mathrm{P}-\mathrm{Br}$ & 376.13 \\
$\mathrm{Pt}(\mathrm{II}) \mathrm{P}-\mathrm{CH}_{3}$ & 369.15 \\
$\mathrm{Pt}(\mathrm{II}) \mathrm{P}-\mathrm{F}$ & 355.31 \\
$\mathrm{Pt}(\mathrm{II}) \mathrm{P}-\mathrm{H}$ & 350.92 \\
\hline
\end{tabular}

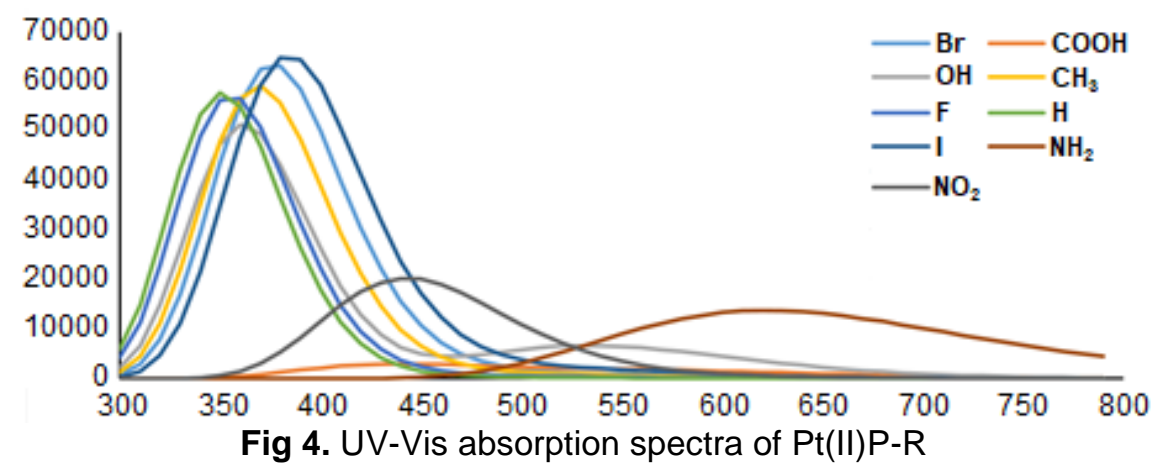

Harno Dwi Pranowo et al. 
tend to have a longer maximum wavelength than electron withdrawing $\left(\mathrm{NO}_{2}, \mathrm{COOH}, \mathrm{I}, \mathrm{Br}\right.$, and $\left.\mathrm{F}\right)$. If we compare the $E_{g}$ values of the complexes, we can conclude that electron donating substituent tend to have lower band gap energy and higher maximum wavelength. It is related with Planck equation that $E \sim 1 \lambda$ so that there is a correlation between the energy and wavelength. From this study we can agree that platinum(II) porphyrin that is substituted by electron donating group have semiconductor properties better than electron withdrawing group based on the band gap energy $\left(E_{g}\right)$, DOS abundance, and UV-visible spectra. Electron donating groups have a lower $E_{g}$, lower DOS номо abundance, and higher maximum wavelength of UV-Visible spectra where in particular, $\mathrm{Pt}(\mathrm{II})-\mathrm{P}-\mathrm{NH}_{2}$ can be recommended as a highly potential semiconductor material. Woodward-Fieser rule suggests that the substituent on the organic molecule shifted the spectra to the longer wavelength for this compound.

\section{CONCLUSION}

The substituent groups affect the semiconductor properties of platinum(II) porphyrin such as the band gap energy $\left(E_{g}\right)$, DOS abundance, and UV-Visible spectra. $\mathrm{Pt}$ (II)-porphyrin substituted with electron donating groups $\left(\mathrm{CH}_{3}, \mathrm{OH}\right.$, and $\left.\mathrm{NH}_{2}\right)$ tend to have the semiconductor properties better than substituted electron withdrawing $\left(\mathrm{NO}_{2}, \mathrm{COOH}, \mathrm{I}, \mathrm{Br}\right.$, and $\left.\mathrm{F}\right)$. Based on the mentioned semiconductor properties, $\mathrm{Pt}(\mathrm{II})-\mathrm{P}-\mathrm{NH}_{2}$ can be recommended as a highly potential semiconductor material.

\section{ACKNOWLEDGEMENT}

We are grateful to Austrian-Indonesian Center for Computational Chemistry Universitas Gadjah Mada, which offer support to this study. Fadjar Mulya would like to thank to LPI, Baktinusa and DIKTI for the scholarship during his study in Universitas Gadjah Mada.

\section{REFERENCES}

[1] Sessler, J.L., and Weghorn, S.J., 1997, Expanded, Contracted, and Isomeric Porphyrins; Tetrahedron Organic Chemistry Series; $1^{\text {st }}$ ed., vol. 15, Pergamon Press, Oxford, U.K.

[2] Utari, Kusumandari, Purnama, B., Mudasir, and Abraha, K., 2016, Surface morphology of Fe(III)porphyrin thin layers as characterized by atomic force microscopy, Indones. J. Chem., 16 (3), 233238.

[3] Harrach, G., Valiscek, Z., and Horvath, O., 2011, Water soluble silver(II) and gold(III) porphyrins: The effect of structural distortion on the photophysical and photochemical behavior, Inorg. Chem. Commun., 14 (11), 1756-1761.

[4] Zheng, W., Shan, N., Yu, L., and Wang, X., 2008, UV-visible, fluorescence and EPR properties of porphyrins and metalloporphyrins, Dyes Pigm., 77 (1), 153-157.

[5] Amao, Y., Yamada, Y., and Aoki, K., 2004, Preparation and properties of dye-sensitized solar cells using chlorophyll derivative immobilized $\mathrm{TiO}_{2}$ film electrode, J. Photochem. Photobiol., A, 164 (13), 47-51.

[6] Wang, X.F., Xiang, J., Wang, P., Koyama, Y., Yanagida, S., Wada, Y., Hamada, K., Sasaki, S., and Tamiaki, H., 2005, Dye-sensitized solar cells using chlorophyll a derivative as the sensitizer and carotenoid having different conjugation length as redox spacers, Chem. Phys. Lett., 408 (4-6), 409414.

[7] Zhang, C.R., Han, L.H., Zhe, J.W., Jin, N.Z., Shen, Y.L., Gong, J.J., Zhang, H.M., Chen, H.Y., and Liu, Z.J., 2014, The role of terminal groups in electronic structures and related properties: The case of pushpull porphyrin dye sensitized for solar cells, Comput. Theor. Chem., 1039, 62-70.

[8] Mulya, F, Santoso, G.A., Aziz, H.A, and Pranowo H.D., 2016, Design a better metalloporphyrin semiconductor: A theoretical studies on the effect of substituents and central ions, AIP Conf. Proc., 1755 (1), 080006.

[9] Aziz, H.A., Santoso, G.A., Mulya, F., and Pranowo H.D., 2017, Molecular and electronic structure of some symmetrically meso-substituted $\mathrm{Hg}(\mathrm{II})$ porphyrin complexes, Asian J. Chem., 29 (10), 2224-2226.

[10] Shalabi, A.S., Assem, M.A., Soliman, K.A., El Mahdy, A.M., and Taha, H.O., 2014, Performance of metalloporphyrin malonic acid as dye-sensitized solar cells assessed by density functional theory, Mater. Sci. Semicond. Process., 26, 119-129.

[11] Tai, C.K., Chuang, W.H., and Wang, B.C., 2013, Substituted group and side chain effects for the porphyrin and zinc(II)-porphyrin derivatives: A DFT and TD-DFT study, J. Lumin., 142, 8-16.

[12] Barbee, J., and Kuznetsov, A.E., 2012, Revealing substituent effects on the electronic structure and planarity of Ni-porphyrins, Comput. Theor. Chem., 981, 73-85.

[13] Rovira, C., Kunc, K., Hutter, J., Ballone, P., and Parrinello, M., 1997, Equilibrium geometries and electronic structure of iron-porphyrins complexes: A density functional study, J. Phys. Chem. A, 1001 (47), 8914-8925.

[14] Paul-Roth, C.O., Drouet, S., Merhi, A., Williams, J.A.G., Gildea, L.F., Pearson, C., and Petty, M.C., 2013, Synthesis of platinum complexes of fluorenyl- 
substituted porphyrin used as phosphorescent dyes for solution-processed organic light-emitting devices, Tetrahedron, 69, 9625-9632.

[15] Chen, H.C., Hetterscheid, D.G.H., Williams, R.M., van der Vlugt, J., Reek, J.N.H., and Brouwer, A.M., 2009, Platinum(II) porphyrin as a sensitizer for visible-light driven water oxidation in neutral phosphate buffer, Energy Environ. Sci., 8 (3), 975982.

[16] Mink, L.M., Neitzel, M.L., Bellomy, L.M., Falvo, R.E., Boggess, R.K., Trainum, B.T., and Yeaman, P., 1997, Platinum(II) and platinum(IV) porphyrin complexes: Synthesis, characterization, and electrochemistry, Polyhedron, 16 (16), 2809-2817.

[17] Milgrom, L.R., Zuurbier, R.J, Gascoyne, J.M., Thompsett, D., and Moore, B.C., 1994, Platinum porphyrins-V. Multinuclear NMR of some platinum(IV) porphyrins, Polyhedron, 13 (2), 209214.

[18] Milgrom, L.R., Sheppard, R., Slawin, A.M.Z., and Williams, D., 1988, X-ray crystal structure of $2,3,7,8,12,13,17,18$

octaethylpoprhyrinatoplatinum(II) (PtOEP): Potential for correlation of meso-carbon bond-angle with one bond coupling constant in some diamagnetic metal complex of OEP, Polyhedron, 7 (1), 57-61.

[19] Frisch, M.J., Trucks, G.W., Schlegel, H.B., Scuseria, G.E., Robb, M.A., Cheeseman, J.R., Scalmani, G., Barone, V., Mennucci, B., Petersson, G.A., Nakatsuji, H., Caricato, M., Li, X., Hratchian, H.P., Izmaylov, A.F., Bloino, J., Zheng, G., Sonnenberg, J.L., Hada, M., Ehara, M., Toyota, K., Fukuda, R., Hasegawa, J., Ishida, M., Nakajima, T., Honda, Y., Kitao, O., Nakai, H., Vreven, T., Montgomery, Jr.J.A., Peralta, J.E., Ogliaro, F., Bearpark, M., Heyd, J.J., Brothers, E., Kudin, K.N., Staroverov, V.N., Keith, T., Kobayashi, R., Normand, J., Raghavachari, K., Rendell, A., Burant, J.C., lyengar, S.S., Tomasi, J.,
Cossi, M., Rega, N., Millam, J.M., Klene, M., Knox, J.E., Cross, J.B., Bakken, V., Adamo, C., Jaramillo, J., Gomperts, R., Stratmann, R.E., Yazyev, O., Austin, A.J., Cammi, R., Pomelli, C., Ochterski, J.W., Martin, R.L., Morokuma, K., Zakrzewski, V.G., Voth, G.A., Salvador, P., Dannenberg, J.J., Dapprich, S., Daniels, A.D., Farkas, Ö., Foresman, J.B., Ortiz, J.V., Cioslowski, J., and Fox, D.J., 2009, Gaussian, Gaussian, Inc., Wallingford, CT.

[20] O’Boyle, N.M, Tenderholt, A.L., and Langner, K.M., 2008, cclib: A library for package-independent computational chemistry algorithms, J. Comput. Chem., 29 (5), 839-845.

[21] Young, D.C, 2001, Computational Chemistry, John Wiley \& Sons, New York.

[22] West, A.R, 1989, Solid State Chemistry and Its Applications, John Wiley \& Sons, Singapore.

[23] Martins, J.L., 1999, Density Functional Theory, VUB University Press, Brussels.

[24] Yu, P.Y., and Cardona, M., 2010, Fundamentals of Semiconductors - Physics and Materials Properties, Springer, Heidelberg.

[25] Kruse, H., Goerigk, L., and Grimme, S., 2012, Why the standard B3LYP/6-31* model chemistry should not be used in DFT calculations of molecular thermochemistry: Understanding and correcting the problems, J. Org. Chem., 77 (23), 10824-10834.

[26] Bryantsev, V.S., Diallo, M.S., van Duin, A.C.T., and Goddard III, W.A., 2009, Evaluation of B3LYP, X3LYP and M06-class density functional for predicting binding energies of neutral, protonated and deprotonated water clusters, J. Chem. Theory Comput., 5 (4), 1016-1026.

[27] Mitchell, B.S., 2004, An Introduction to Material Engineering and Science for Chemicals and Material Engineers, Wiley Interscience, New Jersey. 